\title{
Türkçenin yabancı dil olarak öğretimi okuma kitaplarının etkinlikler, basit zamanlar, birleşik çekimler ve ek fiil kullanımı açısından incelenmesi
}

Seda KAYA'

\section{Salih Kürşad DOLUNAY²}

\begin{abstract}
APA: Kaya, S.; Dolunay, S. K. (2020). Türkçenin yabancı dil olarak öğretimi okuma kitaplarının etkinlikler, basit zamanlar, birleşik çekimler ve ek fiil kullanımı açısından incelenmesi. RumeliDE Dil ve Edebiyat Araştırmaları Dergisi, (Ö7), 1-14. DOI: 10.2900o/rumelide.808156.
\end{abstract}

\section{$\ddot{\mathbf{O} z}$}

$\mathrm{Bu}$ araştırmada, düzeylere göre (A1-A2, A2-B1 ve B1-B2) hazırlanmış, Türkçenin yabancı dil olarak ögretiminde kullanılan okuma kitaplarındaki basit zamanlar, birleşik çekimler ve ek fiilin kullanım sıklıkları ve öğretim etkinliklerinin türü incelenmiş, bunların düzeylere uygunluğu belirlenmeye çalışılmıştır. Araştırmaya veri toplamak için Yunus Emre Enstitüsünce hazırlanmış üç okuma kitabı seçilmiştir. İncelenecek kitaplar, rastlantısal örnekleme yoluyla belirlenmiş ve bunların içerik analizi yapılmıştır. İçerik analizi yapılırken 2 alan uzmanınca hazırlanmış 3 ana başlık ve 31 alt başlıktan oluşturulan çekimli eylem belirtke tablosu kullanılmıştır. Bu tablodaki başlıklar Maxqda nitel veri analiz programına kodlanmış; basit zamanlar, birleşik çekimler ve ek fiillerin kitaplarda geçme sıklığı belirlenmiştir. Daha sonra bu kitaplarda kullanılan etkinliklerin türleri belirlenmiş ve etkinliklerin sıklıkları hesaplanmıştır. Buna göre, okuma kitaplarında basit zaman ve birleşik çekimler en çok B1-B2 ve A1-A2; en az ise A2-B1 düzeyi; ek eylemler ise en çok A2-B1, B1-B2; en az ise A1-A2 düzeyi okuma kitaplarında geçmektedir. Okuma kitaplarında en çok kullanılan etkinlik türlerinin eşleştirme, sıralama (kontrollü yazma), boşluk doldurma, doğru kelimeyi seçme, doğruyanlış soruları olduğu bulgulanmıştır. En az kullanılan etkinlik türleri ise çoktan seçmeli, var-yok soruları ve gönderim sorusudur. Etkinlikler daha çok bilgi-kavrama düzeyini ölçmeye yöneliktir. Sonuç olarak Türkçenin yabancı dil olarak öğretimi amacıyla hazırlanan ders kitapları, okuma kitapları ve etkinliklerin, düzeylere uygun dilbilgisel yapıları ve etkinlik türlerini barındırması gerekmektedir. Dil öğretim materyallerinin öğrencilerin dil düzeylerine uygun hazırlanması daha verimli bir öğretim sürecini de beraberinde getirecektir.

Anahtar kelimeler: Türkçenin yabancı dil olarak öğretimi (TYDÖ), zamanlar, birleşik çekim, okuma kitapları, etkinlikler.

\section{Analyzing of Turkish teaching as a foreign language reading books in terms of activities, simple tenses, compound conjugations and substantive verbs}

\begin{abstract}
In this study, the frequency of use of simple tenses, compound conjugations and substantive verbs in the reading books used in teaching Turkish as a foreign language, prepared according to levels (A1-A2, A2-B1 and B1-B2) and the type of teaching activities were examined, and their suitability to the levels was tried to be determined. Three reading books prepared by Yunus Emre Institute were

1 Arş. Gör.; Bolu Abant İzzet Baysal Üniversitesi, Eğitim Fakültesi, Türkçe ve Sosyal Bilimler Bölümü, Türkçe Eğitimi ABD (Bolu, Türkiye), sedakaya@ibu.edu.tr, ORCID ID: 0000-0002-4658-4924 [Makale kayıt tarihi: 15.08.2020-kabul tarihi: 20.09.2020; DOI: 10.29000/rumelide.808156]

Dr. Öğr. Üyesi, Bolu Abant İzzet Baysal Üniversitesi, Eğitim Fakültesi, Türkçe ve Sosyal Bilimler Bölümü, Türkçe Eğitimi ABD (Bolu, Türkiye), dolunay_k@ibu.edu.tr, ORCID ID: 0000-0002-2931-405X
\end{abstract}


Analyzing of Turkish teaching as a foreign language reading books in terms of activities, simple tenses, compound conjugations and substantive verbs / S. Kaya; S. K. Dolunay (pp. 1-14)

selected to collect data for the study. The books to be examined were determined by random sampling and their content analysis was made. While analyzing the content, a finite verb signal table consisting of 3 main titles and 31 subtitles prepared by 2 field experts was used. The headings in this table are coded into the Maxqda qualitative analysis program; the frequency of simple tenses, compound conjugations and substantive verbs in the books has been determined. Then, the types of activities used in these books were described and the frequencies of the activities were calculated. According to this, simple tenses and compound conjugations are mostly used at B1-B2 and A1-A2 levels; at least used at the level of A2-B1; substantive verbs are mostly used at A2-B1, B1B2 level; they are least used in A1-A2 level reading books. It has been found that the most commonly used activity types in reading books are matching, sorting (controlled writing), filling in the gap, choosing the right word, and true-false questions. The least used activity types are multiple choice, yes-no questions and submission questions. Activities are mostly aimed at measuring the level of knowledge-comprehension. As a result, the textbooks, reading books and activities prepared for the purpose of teaching Turkish as a foreign language should contain grammatical structures and activity types appropriate to the levels. The preparation of language teaching materials in accordance with the language levels of the students will bring a more efficient teaching process.

Keywords: Teaching Turkish as a foreign language (TTFL), tenses, compound conjugations, Turkish teaching reading books, activities.

\section{Giriş}

Türkçenin yabancı dil olarak öğretimi, ülkemizde ve yurt dışında son yıllarda giderek önem kazanan bir alan hâline gelmiştir. Buna koşut olarak da ülkemizin birçok üniversitesinde Türkçe öğretim merkezleri açılmış, ayrıca Yunus Emre Enstitüsü de gerek Türkçenin yabancı dil olarak öğretiminde gerekse Türk kültürünün yurt dışında tanıtılmasında önemli görevler üstlenmiştir. Bunların yanı sıra Türkçeyi yabancı dil olarak öğreten özel kurumlar da bulunmaktadır. Bu kurumlar, öğretim sürecinin etkili ve verimli olması için birtakım materyaller de kullanmaktadırlar. Bunlardan biri de düzeylere göre hazırlanmış ders kitaplarıdır. Ders kitaplarından başka, eğitim öğretim sürecinde öğrencilerin yararlanması ve kendilerini geliştirmeleri için birtakım yardımcı materyallerden de yararlanılır.

Dil öğretiminde kullanılan ders materyalleri, uygulayıcıların yanı sıra araştırmacılar için de önemlidir. Çünkü araştırmacılar bu materyalleri türlü açılardan inceleyerek dil öğretiminin daha etkili ve verimli olmasına yönelik belirlemelerde bulunur, konuyla ilgilenenlere öneriler sunarlar. Türkçenin yabancı dil olarak öğretiminde de bu amaçla pek çok çalışma yapılmıştır. Bu araştırmanın konusu olan ve yardımcı ya da bütünleyici kaynaklar olarak nitelendirilebilecek okuma kitapları da incelenmesi gereken öğretim materyalleri arasında yer alır. Okuma kitapları; Türkçenin yabancı dil olarak öğretiminde öğrencilerin eğitim öğretim sürecinde öğrendiklerini pekiştirebilmeleri ve kendilerini geliştirebilmeleri için gerekli kaynaklardandır. Bu kaynaklar hazırlanırken hedef kitlenin düzeyinin yanı sıra ilgi ve gereksinimleri, metinlerdeki türlü biçimbilimsel ve sözdizimsel dil yapıları, tümcelerin ve metinlerin uzunluk ya da kısalığı, sözcük seçimi gibi birtakım özelliklere de dikkat edilmesi gerekmektedir. Bu bakımdan bu tür kitapları hazırlamak zahmetlidir ve birçok unsura aynı anda dikkat etmeyi gerektirir.

Okuma kitaplarındaki metinlerle ilgili etkinliklerin, öğrencilerin üretici dil becerilerini harekete geçirecek üst düzey dil becerilerini geliştirmeye yönelik olması gerekir. Kaili ve Çeltek'e göre (2010) göre özellikle okuma sonrası etkinlikleri, öğrencilerin bir metni anlayıp anlamadıklarını ölçerek 
öğrencileri o metnin daha derin bir analizini yapmaya yönlendirmekte; metindeki ana düşünceyi ve metinde sezdirilenleri anlamalarını, metni yeniden kurgulamalarını sağlamakta, ayrıca yazılı ve sözlü anlatım etkinlikleri için de bir temel oluşturmaktadır. Nitekim Türkçenin yabancı dil olarak öğretimi için hazırlanan ders kitaplarının öğrenci düzeylerine uygun olması ve öğrencilerin düşünsel becerilerini geliştirecek etkinlikler bulundurması dil öğretiminin amacına ulaşması bakımından önemlidir (Biçer, 2019: 181). Ders kitapları için belirtilen bu nitelikler, okuma kitapları için de geçerlidir. Yine okuma metinlerinde kullanılan birtakım dilbilgisel yapıların, örneğin çekimli eylemlerin de kur düzeylerine göre iyi belirlenmesi gerekmektedir. Aksi takdirde öğrenci hiç karşlaşmadığı bir çekimli eylemle karşılaştığında öğrenme isteğine ket vurulacaktır. Bu yüzden Türkçenin yabancı dil olarak öğretiminde ders kitapları, okuma kitapları ya da sınavlar hazırlanırken öğrencilerin dil düzeyleri göz önünde bulundurulmalı, öğretim etkinlikleri öğrencilerde ilgi uyandıracak ve onların dil öğrenme süreçlerini etkili geçirmelerini sağlayacak nitelikte olmalıdır.

\section{Araştırmanın amacı ve önemi}

Alanyazın incelendiğinde Türkçenin yabancı dil olarak öğretimi konusunda okuma kitapları üzerine yeterince inceleme olmadığı, araştırmaların daha çok ders kitapları üzerinde yoğunlaştığı belirlenmiştir. Var olan çalışmaların, ders kitaplarındaki ve okuma kitaplarındaki metinlerin incelenmesi (Şimşek, 2011), temel düzey okuma kitaplarının fiziksel yapı, alıştırma tipleri ve içerik açısından incelenmesi (Gün ve Şimşek 2017), ders kitaplarındaki okuma metinlerinin yanı sıra metin altı sorularının incelenmesi (Aydoğan ve Aytekin, 2019; Biçer, 2019; Kana ve Güney 2020; Şahin, 2010; Ulutaş ve Kara 2019) üzerine olduğu görülmektedir. Öte yandan Türkçenin yabancı dil olarak öğretiminde eylem çekimleri, kipler (bildirme kipleri, tasarlama kipleri), kiplik, ek eylem, birleşik çekim (birleşik zaman) gibi konular da öğretim sırasında üzerinde önemle durulan konular arasında yer almaktadır. Bu konuların öğretimine yönelik olarak alanyazında görülen yayınlar da (Eren Ökten ve Sauner-Leroy, 2016; Fidan ve Aksu 2011; Güçer, 2010; Gümüş, 2016; Haciömeroğlu, 2007; Karababa ve Saltık, 2012; Kılıçarslan, 2015; Kırbaş, 2019; Sarıçiyil, 2008; Şeylan, 2013; Şeylan, 2015; Ünlücömert, 2010; Yolcusoy, 2008) şeklinde belirtilebilir. Türkçenin yabancı dil olarak öğretiminde, ders kitaplarında dil bilgisi konularının geçme sıklığı ve düzeye göre öğretim sırasına ilişkin çalışmalar olsa da (Arslan 2011; Doyumğaç 2017; Erol 2008; Fidan 2016; Gümüş 2016; Kalfa 2018; Karatay ve Kaya 2019a, 2019b; Kurt 2016; Özdemir 2011; Pirinç 2010; Şeylan 2013) okuma kitaplarında da düzeylere göre dil bilgisi konularının incelenmesi ve hangi tür etkinliklerin hangi sıklıkla kullanıldığının belirlenmesi üzerine karşılaştırmalı bir çalışmaya ihtiyaç olduğu görülmektedir. Bu çalışmada düzeylere göre (A1-A2, A2-B1 ve B1-B2) hazırlanmış Türkçenin yabancı dil olarak öğretiminde kullanılan okuma kitaplarındaki basit zamanlar, birleşik çekimler ve ek eylemin kullanım sıklıkları belirlenmiş ve öğretim etkinliklerinin türü incelenerek bunların düzeylere uygunluğu belirlenmeye çalışılmıştır. Yapılacak böyle bir çalışmanın, özellikle Türkçenin yabancı dil olarak öğretiminde program hazırlayıcılara, ders kitabı, yardımcı (destekleyici) kaynak hazırlayanlara ve uygulayıcılara yararlı olacağı düşünülmüştür.

\section{Araşturmanın problemleri}

Türkçenin yabancı dil olarak öğretimi okuma kitaplarındaki metinlerde ve etkinliklerde, düzeylere göre (A1-A2, A2-B1 ve B1-B2) hangi basit zamanlar ve birleşik çekimlere ne sıklıkla yer verilmiştir?

Türkçenin yabancı dil olarak öğretimi okuma kitaplarındaki metinlerde ve etkinliklerinde, düzeylere göre (A1-A2, A2-B1 ve B1-B2) ek eylemin hangi çekimlerine ne sıklıkla yer verilmiştir? 

and substantive verbs / S. Kaya; S. K. Dolunay (pp. 1-14)

Türkçenin yabancı dil olarak öğretimi okuma kitaplarında hangi tür etkinliklere ne sıklıkla yer verilmiştir?

\section{Araştırmanın yöntemi ve deseni}

Bu çalışma, Türkçenin yabancı dil olarak öğretiminde yardımcı kaynak olarak hazırlanmış A1-A2, A2B1 ve B1-B2 düzey okuma kitaplarındaki metinlerde ve etkinliklerde basit zamanlar, birleşik çekimler ve ek eylemin düzeylere göre kullanım sıklıklarını, hangi tür etkinliklerin ne sıklıkla kullanıldığını tespit etmek amacıyla hazırlanmıştır. Çalışmaya veri toplamak amacıyla doküman inceleme tekniğine ve uzman görüşüne başvurulmuştur. Doküman inceleme çalışılacak konular ile ilgili olarak yazılı ve basılı belgelerin analizini içerir (Yıldırım ve Şimşek 2008, 110). Okuma kitaplarındaki metinlerde ve etkinliklerde basit zamanlar, birleşik çekimler ve ek eylemin ne sıklıkla geçtiğini, hangi tür etkinliklerin ne sıklıkla kullanıldığını belirlemek amacıyla araştırmanın birinci aşamasında, basit zamanları, birleşik çekimleri, ek eylem çekimlerini ana ve alt temalara ayırmak, terminoloji birliği sağlamak, konuları ayrıntılı incelemek için bir çekimli belirtke tablosu (ÇEBT) oluşturulmuştur. Bunun için üç alan uzmanının görüşüne başvurulmuştur. Uzman görüşü alınarak tablonun ana ve alt temalarının son şekline karar verilmiştir. Araştırmada incelenecek okuma kitapları, seçkisiz atama tekniği ile belirlenmiştir. Seçkisiz atama tekniğinin kullanıldığı araştırmalarda örneklem tamamen rastgele seçilir (Yıldırım ve Şimşek, 2013). Bunun için araştırma konusuyla ilgili 1 yayınevinin A1-A2, A2-B1 ve B1-B2 okuma kitapları incelenmiş; bunların içinden araştırmanın amacına uygun 3 okuma kitabının incelenmesine karar verilmiştir. İncelenen okuma kitapları aşă̆ıdadır:

Yunus Emre Enstitüsü (2015), Mesnevi'den Okumalar (Türkçe Okuyorum) A1-A2, İstanbul: Yunus Emre Enstitüsü Yayınları.

Yunus Emre Enstitüsü (2015), Türk Romanından Seçmeler III (Türkçe Okuyorum) B1-B2, İstanbul: Yunus Emre Enstitüsü Yayınları.

Yunus Emre Enstitüsü (2015), İstanbul'u Geziyorum A2-B1, İstanbul: Yunus Emre Enstitüsü Yayınları.

\section{Veri toplama aracı}

Çalışmanın başlangıcında üç uzman görüşüne başvurularak "Çekimli Eylem Belirtke Tablosu (ÇEBT)" oluşturulmuş ve bu belirtke tablosu veri toplama aracı olarak kullanılmıştır. ÇEBT, "basit zamanlar, birleşik çekimler ve ek eylemler" olmak üzere 3 ana tema ve bunların altında yer alan 31 alt temadan oluşmaktadır.

\section{Veri toplama süreci}

ÇEBT'deki basit zamanlar, birleşik çekimler ve ek eylem çekimleri "Yunus Emre Enstitüsü, Mesnevi'den Okumalar (Türkçe Okuyorum) A1-A2 düzeyi, Yunus Emre Enstitüsü, İstanbul'u Geziyorum A2-B1 düzeyi, Türk Romanından Seçmeler III (Türkçe Okuyorum) B1-B2 düzeyi için her okuma metni ve etkinlikte ayrı ayrı incelenmiştir. Bunun yanı sıra kitaplardaki etkinliklerin türü belirlenerek kategorilere ayrılmıştır. Böylelikle okuma kitaplarındaki metinlerin ve etkinliklerin kitaplardaki düzeye uygunluğunu betimlemek için veri elde edilmeye çalışılmıştır. 


\section{Verilerin analizi}

Verilerinin çözümlenmesinde içerik inceleme tekniklerinden sıklık incelemesi kullanılmıştır. İlk olarak ÇEBT ile belirlenen basit zamanlar, birleşik çekimler ve ek eylem kullanımlarının A1-A2, A2-B1 ve B1B2 düzeyine göre hazırlanmış Türkçenin yabancı dil olarak öğretimi okuma kitaplarında yer alan metinler ve etkinliklerdeki sıklıkları Maxqda programı ile belirlenmiştir. Bu inceleme sırasında, belirtilen konular, metinler ve metin sonu her etkinlikte ayrı ayrı tespit edilmiş, sıklıkları alınmıştır. Daha sonra okuma kitaplarındaki etkinliklerin türleri ve hangi etkinlik türüne ne sıklıkla yer verildiği belirlenmiştir.

\section{Bulgular}

$\mathrm{Bu}$ bölümde Türkçenin yabancı dil olarak öğretimi için düzeylere göre hazırlanmış okuma kitaplarındaki basit zamanlar, birleşik çekimler ve ek eylemlerin kullanım sıklıklarına yer verilmiştir.

Birinci alt problem: Türkçenin yabancı dil olarak öğretimi okuma kitaplarındaki metinlerde ve etkinliklerde, düzeylere göre (A1-A2, A2-B1 ve B1-B2) hangi basit zamanlar ve birleşik çekimlere ne sıklıkla yer verilmiștir?

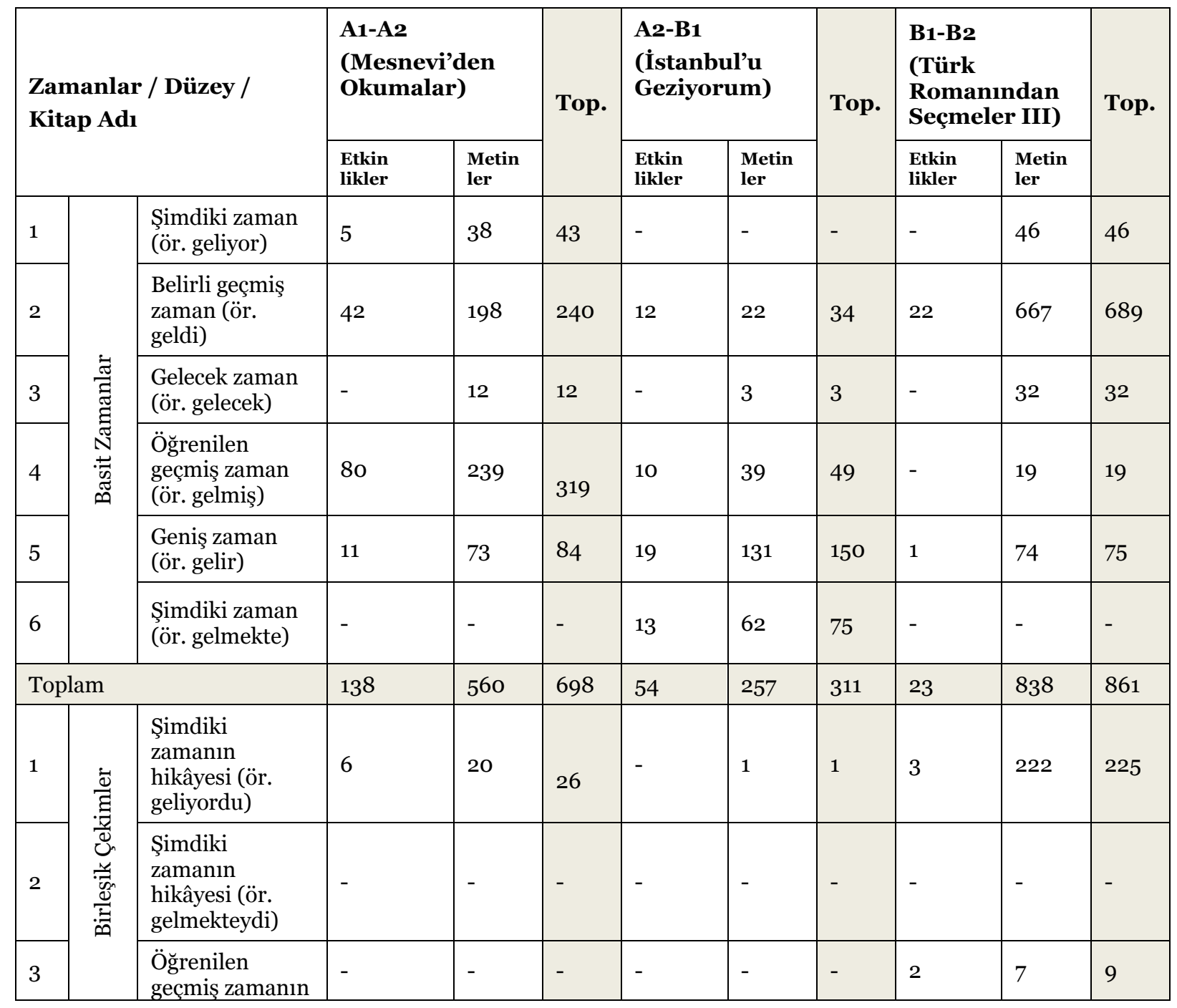


Analyzing of Turkish teaching as a foreign language reading books in terms of activities, simple tenses, compound conjugations and substantive verbs / S. Kaya; S. K. Dolunay (pp. 1-14)

\begin{tabular}{|c|c|c|c|c|c|c|c|c|c|c|}
\hline & $\begin{array}{l}\text { hikâyesi (ör. } \\
\text { gelmişti) }\end{array}$ & & & & & & & & & \\
\hline 4 & $\begin{array}{l}\text { Geniş zamanın } \\
\text { hikâyesi (ör. } \\
\text { gelirdi) }\end{array}$ & 1 & 2 & 3 & - & - & - & 1 & 22 & 23 \\
\hline 5 & $\begin{array}{l}\text { Gelecek } \\
\text { zamanın } \\
\text { hikâyesi (ör. } \\
\text { gelecekti) }\end{array}$ & - & - & - & - & - & - & 1 & 4 & 5 \\
\hline 6 & $\begin{array}{l}\text { Gereklilik } \\
\text { kipinin hikâyesi } \\
\text { (ör. gelmeliydi) }\end{array}$ & - & - & - & - & - & - & - & - & - \\
\hline 7 & $\begin{array}{l}\text { Gerçekleşmemiş } \\
\text { koşul (ör. } \\
\text { gelseydi) }\end{array}$ & 1 & 2 & 3 & - & - & - & - & - & - \\
\hline 8 & $\begin{array}{l}\text { Şimdiki } \\
\text { zamanın } \\
\text { rivâyeti (ör. } \\
\text { geliyormuş) }\end{array}$ & 3 & 8 & 11 & - & - & - & - & 1 & 1 \\
\hline 9 & $\begin{array}{l}\text { Öğrenilen } \\
\text { geçmiş zamanın } \\
\text { rivâyeti (ör. } \\
\text { gelmişmiş) }\end{array}$ & - & - & - & - & - & - & - & - & - \\
\hline 10 & $\begin{array}{l}\text { Geniş zamanın } \\
\text { rivâyeti (ör. } \\
\text { gelirmiş) }\end{array}$ & 1 & 1 & 2 & - & - & - & - & - & - \\
\hline 11 & $\begin{array}{l}\text { Gelecek } \\
\text { zamanın } \\
\text { rivâyeti (ör. } \\
\text { gelecekmiş) }\end{array}$ & - & - & - & - & - & - & - & 1 & 1 \\
\hline 12 & $\begin{array}{l}\text { Şimdiki } \\
\text { zamanın } \\
\text { rivâyeti } \\
\text { (gelmekteymiş) }\end{array}$ & - & - & - & - & - & - & - & - & - \\
\hline 13 & $\begin{array}{l}\text { Şart kipinin } \\
\text { rivayeti(ör. } \\
\text { gelseymiş) }\end{array}$ & - & - & & - & - & & - & - & - \\
\hline 14 & $\begin{array}{l}\text { Gereklilik } \\
\text { kipinin rivayeti } \\
\text { (ör. } \\
\text { gelmeliymiş) }\end{array}$ & - & - & - & - & - & - & - & - & - \\
\hline 15 & $\begin{array}{l}\text { Şimdiki } \\
\text { zamanın koşulu } \\
\text { (ör. geliyorsa) }\end{array}$ & - & - & - & - & 6 & 6 & - & 3 & 3 \\
\hline 16 & $\begin{array}{l}\text { Belirli geçmiş } \\
\text { zamanın koşulu } \\
\text { (ör. geldiyse) }\end{array}$ & - & 2 & 2 & - & - & - & - & - & - \\
\hline 17 & $\begin{array}{l}\text { Ö̆ğrenilen } \\
\text { geçmiş zamanın } \\
\text { koşulu (ör. } \\
\text { gelmişse) }\end{array}$ & - & - & - & - & - & - & - & - & - \\
\hline 18 & $\begin{array}{l}\text { Geniş zamanın } \\
\text { koșulu (ör. }\end{array}$ & - & 13 & 13 & - & 1 & 1 & - & 25 & 25 \\
\hline
\end{tabular}

Adres 1 Address 


\begin{tabular}{|c|c|c|c|c|c|c|c|c|c|c|}
\hline & gelirse) & & & & & & & & & \\
\hline 19 & $\begin{array}{l}\text { Gelecek } \\
\text { zamanın koşulu } \\
\text { (ör. gelecekse) }\end{array}$ & - & 1 & 1 & - & - & - & - & 1 & 1 \\
\hline 20 & $\begin{array}{l}\text { Gereklilik } \\
\text { kipinin koşulu } \\
\text { (ör. gelmeliyse) }\end{array}$ & - & - & - & - & - & - & - & - & - \\
\hline 21 & $\begin{array}{l}\text { Şimdiki } \\
\text { zamanın koşulu } \\
\text { (ör. } \\
\text { gelmekteyse) }\end{array}$ & - & - & - & - & - & - & - & - & - \\
\hline \multicolumn{2}{|c|}{ Toplam } & 12 & 49 & 61 & - & 8 & 8 & 7 & 286 & 293 \\
\hline \multicolumn{2}{|c|}{$\begin{array}{l}\text { tüm zaman konularinin } \\
\text { toplami }\end{array}$} & \multicolumn{3}{|c|}{$698+61=759$} & \multicolumn{3}{|c|}{$311+8=319$} & \multicolumn{3}{|c|}{$861+293=1154$} \\
\hline
\end{tabular}

Tablo 1. Basit zamanlar ve birleşik çekimlerin YEE A1-A2, A2-B1 ve B1-B2 düzeyi Türkçe öğretimi okuma kitaplarında işlenişi

Tablo 1'de Yunus Emre Enstitüsünce Türkçenin yabancı dil olarak öğretimi amacıyla hazırlanmış okuma kitaplarındaki metinler ve etkinliklerde basit zamanlar ile birleşik çekimlerin geçme sıklıkları bulunmaktadır. Buna göre, YEE A1-A2 düzeyi okuma kitabında basit zamanlardan en çok "öğrenilen geçmiş zaman" (s 319), "belirli geçmiş zaman" (s 240), "geniş zaman" (s 84); en az "şimdiki zaman" (s 43) ve "gelecek zaman" (s 12) kullanılmıştır. Şimdiki zaman (-mAktA) ise hiç geçmemektedir.

A2-B1 düzeyi okuma kitabında ise basit zamanlardan en çok "geniş zaman" (s 150), şimdiki zaman (mAktA) (s 75); en az "öğrenilen geçmiş zaman” (s 49), "belirli geçmiş zaman” (s 34), "gelecek zaman” (s 3)" kullanılmıştır. Kitabın adında şimdiki zaman (-yor) kullanılmış ama etkinlik ve metinlerde şimdiki zaman (-yor) kullanılmamıştır.

B1-B2 düzey okuma kitabında ise basit zamanlardan en çok "belirli geçmiş zaman" (s 689); en az "geniş zaman” (s 75), "şimdiki zaman (-yor)" (s 46), "gelecek zaman” (s 32), "öğrenilen geçmiş zaman” (s 19) kullanılmıştır. Şimdiki zaman (-mAktA) ise hiç kullanılmamıştır.

Birleşik çekimler konusunda ise YEE A1-A2 düzeyi okuma kitabında "şimdiki zamanın hikâyesi(yordu)" (s 26), "geniş zamanın koşulu" (s 13) ve "şimdiki zamanın rivâyeti (-yormuş)" (s 11); en az "geniş zamanın hikâyesi" (s 3), "gerçekleşmemiş koşul" (s 3), "geniş zamanın rivâyeti" (s 2), "belirli geçmiş zamanın koşulu” (s 2), gelecek zamanın koşulu (s 1) birleşik çekimlerine yer verilmiştir. Öğrenilen geçmiş zamanın hikâyesi, gelecek zamanın hikâyesi, şimdiki zamanın hikâyesi (-mAktAydI), öğrenilen geçmiş zamanın rivayeti, gelecek zamanın rivayeti, şimdiki zamanın rivayeti (-mAktAymIş), şimdiki zamanın koşulu (-yorsa), gereklilik kipinin koşulu, gereklilik kipinin hikâyesi, şart kipinin rivayeti, gereklilik kipinin rivayeti, öğrenilen geçmiş zamanın koşulu ve şimdiki zamanın koşulu (mAktAysA)" birleşik çekimleri hiç geçmemektedir.

A2-B1 düzeyi okuma kitabında birleşik çekimlerden "şimdiki zamanın koşulu (-yorsa)" (s 6); en az "şimdiki zamanın hikâyesi (-yordu)" (s 1) ve "geniş zamanın koşulu" (s 1) birleşik çekimlerine yer verilmiştir. "Öğrenilen geçmiş zamanın hikâyesi, geniş zamanın hikâyesi, gelecek zamanın hikâyesi, şimdiki zamanın hikâyesi (-mAktAydI), şimdiki zamanın rivayeti (-yormuş), öğrenilen geçmiş zamanın rivayeti, geniş zamanın rivayeti, gelecek zamanın rivayeti, şimdiki zamanın rivayeti (-mAktAymIş), belirli geçmiş zamanın koşulu, gerçekleşmemiş koşul, gelecek zamanın koşulu, gereklilik kipinin 
Analyzing of Turkish teaching as a foreign language reading books in terms of activities, simple tenses, compound conjugations and substantive verbs / S. Kaya; S. K. Dolunay (pp. 1-14)

koşulu, gereklilik kipinin hikâyesi, şart kipinin rivayeti, gereklilik kipinin rivayeti, öğrenilen geçmiş zamanın koşulu ve şimdiki zamanın koşulu (-mAktAysA)" birleşik çekimleri hiç geçmemektedir.

B1-B2 düzeyi okuma kitabında birleşik çekimlerden en çok "şimdiki zamanın hikâyesi (-yordu)" (s 225), "geniş zamanın hikâyesi” (s 23) ve "geniş zamanın koşulu" (s 25); en az "öğrenilen geçmiş zamanın hikâyesi” (s 9), "gelecek zamanın hikâyesi” (s 5), "şimdiki zamanın koşulu (-yorsa)" (s 3), "şimdiki zamanın rivâyeti (-yormuş)" (s 1), "gelecek zamanın rivâyeti" (s 1) ve "gelecek zamanın koşulu” (s 1) birleşik çekimleri vardır. "Şimdiki zamanın hikâyesi (-maktAydI), geniş zamanın rivâyeti, öğrenilen geçmiş zamanın rivâyeti, şimdiki zamanın rivâyeti (-mAktAymIş), belirli geçmiş zamanın koşulu, gerçekleşmemiş koşul, gereklilik kipinin koşulu, gereklilik kipinin hikâyesi, şart kipinin rivayeti, gereklilik kipinin rivayeti, öğrenilen geçmiş zamanın koşulu ve şimdiki zamanın koşulu (mAktAysA)" birleşik çekimleri geçmemektedir.

İkinci alt problem: Türkçenin yabancı dil olarak öğretimi okuma kitaplarındaki metinlerde ve etkinliklerinde, düzeylere göre (A1-A2, A2-B1 ve B1-B2) ek eylemin hangi çekimlerine ne sıklıkla yer verilmiştir?

\begin{tabular}{|c|c|c|c|c|c|c|c|c|c|c|c|}
\hline \multicolumn{3}{|c|}{$\begin{array}{l}\text { Zamanlar / Düzey / } \\
\text { Kitap Adı }\end{array}$} & \multicolumn{2}{|c|}{$\begin{array}{l}\text { A1-A2 } \\
\text { (Mesnevi'den } \\
\text { Okumalar) }\end{array}$} & \multirow{3}{*}{$\begin{array}{l}\text { Top. } \\
\\
23\end{array}$} & \multicolumn{2}{|c|}{$\begin{array}{l}\text { A2-B1 } \\
\text { (İstanbul'u } \\
\text { Geziyorum) }\end{array}$} & \multirow{3}{*}{$\begin{array}{l}\text { Top. } \\
8\end{array}$} & \multicolumn{2}{|c|}{$\begin{array}{l}\text { B1-B2 } \\
\text { (Türk } \\
\text { Romanından } \\
\text { Seçmeler III) }\end{array}$} & \multirow{3}{*}{$\begin{array}{r}\text { Top. } \\
\\
133\end{array}$} \\
\hline & & & \multirow{2}{*}{$\begin{array}{l}\text { Etkin } \\
\text { likler } \\
5\end{array}$} & \multirow{2}{*}{$\begin{array}{l}\begin{array}{l}\text { Metin } \\
\text { ler }\end{array} \\
18\end{array}$} & & \multirow{2}{*}{$\begin{array}{l}\begin{array}{l}\text { Etkin } \\
\text { likler }\end{array} \\
2\end{array}$} & \multirow{2}{*}{$\begin{array}{l}\begin{array}{l}\text { Metin } \\
\text { ler }\end{array} \\
6\end{array}$} & & \multirow{2}{*}{$\begin{array}{l}\begin{array}{l}\text { Etkin } \\
\text { likler }\end{array} \\
3\end{array}$} & \multirow{2}{*}{$\begin{array}{l}\begin{array}{l}\text { Metin } \\
\text { ler }\end{array} \\
130 \\
\end{array}$} & \\
\hline 1 & \multirow{4}{*}{ 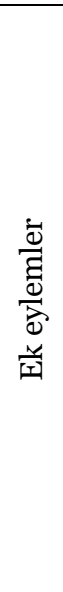 } & $\begin{array}{l}\text { Zamansal ek } \\
\text { eylem (ör. } \\
\text { Hava sıcaktı) }\end{array}$ & & & & & & & & & \\
\hline 2 & & $\begin{array}{l}\text { Ek eylemin } \\
\text { geniş/şimdiki } \\
\text { zamanı (ör. } \\
\text { Hava sıcak) }\end{array}$ & 2 & 63 & 65 & 37 & 187 & 224 & - & 71 & 71 \\
\hline 3 & & $\begin{array}{l}\text { Kanıtsal ek } \\
\text { eylem (ör. } \\
\text { Hava } \\
\text { sicakmış) }\end{array}$ & 9 & 18 & 27 & - & - & - & - & 2 & 2 \\
\hline 4 & & $\begin{array}{l}\text { Ek eylemin } \\
\text { koşulu (ör. } \\
\text { Hava sıcaksa) }\end{array}$ & 6 & - & 6 & 4 & - & 4 & - & 1 & 1 \\
\hline \multicolumn{3}{|c|}{ Toplam } & 22 & 99 & 121 & 43 & 193 & 236 & 3 & 204 & 207 \\
\hline
\end{tabular}

Tablo 2. Ek eylemlerin YEE A1-A2, A2-B1 ve B1-B2 düzeyi Türkçe öğretimi okuma kitaplarında işlenişi

Tablo 2'de Yunus Emre Enstitüsünce Türkçenin yabancı dil olarak öğretimi amacıyla hazırlanmış olan okuma kitaplarında ek eylemlerin geçme sıklıkları bulunmaktadır. Buna göre, YEE A1-A2 düzeyi okuma kitabında ek eylemlerden en çok "ek eylemin geniş/şimdiki zamanı" (s 65); en az "kanıtsal ek eylem (imiş)" (s 27) ve "zamansal ek eylem (idi)" (s 23) ve ek eylemin koşulu (s 6) geçmektedir.

A2-B1 düzeyi okuma kitabında ise ek eylemlerden en çok "ek eylemin geniş/şimdiki zamanı" (s 224); en az "zamansal ek eylem (idi)" (s 8) ve ek eylemin koşulu (s 4) geçmektedir. "Kanıtsal ek eylem (imiş)" ise hiç geçmemektedir. 
B1-B2 düzeyi okuma kitabında ise ek eylemlerden en çok "zamansal ek eylem (idi)" (s 133) ve "ek eylemin geniş/şimdiki zamanı" (s 71); en az "kanıtsal ek eylem (imiş)" (s 2) ve "ek eylemin koşulu” (s 1) geçmektedir.

Üçüncü alt problem: Türkçenin yabancı dil olarak öğretimi okuma kitaplarında hangi tür etkinliklere ne sıklıkla yer verilmiştir?

\begin{tabular}{|l|l|l|l|l|l|}
\hline \multicolumn{2}{|l|}{ Zamanlar / Düzey / Kitap Adı } & $\begin{array}{l}\text { A1-A2 } \\
\text { (Mesneviden } \\
\text { Okumalar) }\end{array}$ & $\begin{array}{l}\text { A2-B1 } \\
\text { (Istanbul'u } \\
\text { Geziyorum) }\end{array}$ & $\begin{array}{l}\text { B1-B2 } \\
\text { (Türk } \\
\text { Romanından } \\
\text { Seçmeler III) }\end{array}$ & Toplam \\
\hline 1 & Boşluk doldurma & - & 5 & - & 5 \\
\hline 2 & Doğru-yanlış soruları & 3 & 2 & - & 5 \\
\hline 3 & Var-yok soruları & - & 2 & - & 2 \\
\hline 4 & Eşleştirme & 4 & 3 & 3 & 10 \\
\hline 5 & Doğru kelimeyi seçme & 4 & 2 & - & 6 \\
\hline 6 & Çoktan seçmeli & 3 & 1 & - & 4 \\
\hline 7 & Siralama (kontrollü yazma) & 3 & 1 & 3 & 7 \\
\hline 8 & Gönderim sorusu & - & 1 & - & 1 \\
\hline Toplam & 17 & 17 & 40 \\
\hline
\end{tabular}

Tablo 3. YEE Türkçenin yabancı dil olarak öğretimi okuma kitaplarındaki etkinlik türleri

Tablo 3'te Yunus Emre Enstitüsünce Türkçenin yabancı dil olarak öğretimi amacıyla hazırlanmış olan okuma kitaplardaki etkinlik türleri vardır. Buna göre, A1-A2 düzeyi okuma kitabında en çok "eşleştirme" (s 4) ve doğru kelimeyi seçme" (s 4); en az "doğru yanlış soruları" (s 3), "çoktan seçmeli” (s 3) ve "sıralama (kontrollü yazma)" (s 3) etkinlik türleri kullanılmıştır. "Boşluk doldurma, var-yok soruları ve gönderim sorusu" ise hiç kullanılmamıştır.

A2-B1 düzeyi okuma kitabında ise en çok "boşluk doldurma" (s 5), "eşleştirme" (s 3); en az "doğruyanlış soruları (s 2), "var-yok soruları" (s 2), "doğru kelimeyi seçme” (s 2), "çoktan seçmeli” (s 1), "sıralama (kontrollü yazma)" (s 1) ve "gönderim sorusu” (s 1) kullanılmıştır.

B1-B2 düzeyi okuma kitabında ise "eşleştirme" (s 3) ve "sıralama (kontrollü yazma)" (s 3) etkinlik türleri kullanılmıştır. "Boşluk doldurma, doğru-yanlış soruları, var-yok soruları, doğru kelimeyi seçme, çoktan seçmeli ve gönderim sorusu” hiç kullanılmamıştır.

\section{Sonuç ve tartışma}

\section{Birinci probleme yönelik sonuçlar}

Yunus Emre Enstitüsü tarafından Türkçenin yabancı dil olarak öğretimi amacıyla hazırlanmış olan A1A2, A2-B1 ve B1-B2 düzeyi okuma kitaplarında geçen basit zamanlar ve birleşik çekimler incelendiğinde YEE basit zamanlara en çok B1-B2 (s 861) ve A1-A2 düzeyi okuma kitabında (s 698); en az A2-B1 düzeyi okuma kitabında (s 311) yer vermiştir. Bağımsız düzey olan B1-B2'de basit zamanlar daha önceki düzeylerde (A1-A2) öğrenilmiş olacağı ve metin uzunlukları da arttığı için basit zamanlar daha çok kullanılmış olabilir. Nitekim aynı durum birleşik çekimlerde de görülmektedir. Birleşik 

and substantive verbs / S. Kaya; S. K. Dolunay (pp. 1-14)

çekimlere en çok B1-B2 düzeyi (s 293); en az A1-A2 düzeyi (s 61) ve A2-B1 düzeyi (s 8) okuma kitaplarında yer verilmiştir. Birleşik çekimlerde iki kip eki bir araya gelir. Birleşik çekimli bir eylemin kullanılması gerektiğinde iki kip eki de bunların işlevleri de bilinmelidir. Bu yüzden A1-A2'de basit zamanların öğretildiği düşünülürse B1-B2 düzeyinde birleşik çekimler daha kolay kullanılabilecektir. Bu durumda kitap yazarları da birleşik çekim kullanma konusunda daha esnek davranacaklardır.

A1-A2 düzeyi okuma kitabında basit zamanlardan "şimdiki zaman (-yor), belirli geçmiş zaman, gelecek zaman, öğrenilen geçmiş zaman ve geniş zaman” kullanılmıştır. Okuma kitabının dil düzeyinin A1 ve A2'ye yönelik olması, basit zamanların da temel düzeyde öğretilen konular arasında yer alması bu basit zamanların kullanılmış olmasına sebep gösterilebilir. Karatay ve Kaya (2019a) yaptıkları çalışmada Yunus Emre Enstitüsünün Türkçenin yabancı dil olarak öğretimi amacıyla hazırlamış olduğu ders kitaplarını da incelemiş ve A1 düzeyinde "şimdiki zaman (-yor), gelecek zaman ve belirli geçmiş zaman"; A2 düzeyinde ise "geniş zaman ve öğrenilen geçmiş zamanın" öğretildiğini belirlemişlerdir. Buradan anlaşılmaktadır ki A1 düzeyindeki bir öğrenci henüz basit zamanların hepsini bilmemektedir. Bu yüzden kullanılan tüm basit zamanları anlamayabilir. Bu çalışmada incelenen okuma kitaplarında dil düzeyinin tek bir düzeye yönelik hazırlanmamış olması yayınevinin bağlamdan ya da metinden hareketle sezdirerek dil öğretimi anlayışını benimsediğini gösterebilir.

Aynı düzey okuma kitabında birleşik çekimlerden "şimdiki zamanın hikâyesi (-yordu), geniş zamanın hikâyesi, şimdiki zamanın rivayeti (-yormuş), geniş zamanın rivayeti, belirli geçmiş zamanın koşulu, gerçekleşmemiş koşul, gelecek zamanın koşulu ve geniş zamanın koşulu" kullanılmıştır. Temel düzey A1-A2'de öğrencinin basit yapılı cümle kurabilmesi, sözlü ve yazılı dilde kendisini ifade edebilmesi yeterlidir. Zaten temel düzey, bir dilin işleyiş mantığının anlaşıldığı ve en temel kuralların öğrenildiği düzeydir. Şimdiki zaman (-yor), belirli geçmiş zaman, geniş zaman, gelecek zaman ve öğrenilen geçmiş zamanın bu düzeyde öğretildiği düşünülürse bu yapılarla bir birey kendisini rahatça ifade edebilir. Bir dil bilgisi yapısının öğrenilmesi için o yapının üretici ve alıcı dil becerilerinde tekrar edilmesi ve pekiştirilmesi gerekmektedir. Dil ile yeni karşılaşılan düzey olan A1-A2'de birçok basit zamanın öğrenildiği düşünülürse iki kip ekinin bir arada kullanılmasını gerektiren birleşik çekimler öğrencide fazladan bilişsel yük oluşturacaktır. Bu yüzden birleşik çekimli eylemlerin bu düzey kitaplardan ziyade bağımsız düzey kitaplarda kullanılması daha etkili bir öğretim sağlayabilir. Çünkü okuma kitapları doğrudan dil öğretim kitapları olmasa da dil öğretimine yardımcı araçlardır.

A2-B1 düzeyi okuma kitabında basit zamanlardan "belirli geçmiş zaman, öğrenilen geçmiş zaman, gelecek zaman, geniş zaman ve şimdiki zaman (-mAktA)" kullanılmıştır. A1 düzeyinde kullanılmamış olan şimdiki zaman (-mAktA) bu düzeyde kullanılmıştır. Şimdiki zaman (-mAktA) sözlü dilde sıklıkla kullanılmamaktadır. Bu yüzden A1 ve A2 düzeyindeki bir öğrencinin bu yapıyı öğrenmesi öncelikli değildir. B1 düzeyinde bu yapının kullanılması dilin mantığını öğrenmiş ve temel düzeydeki dil bilgisi kurallarını kullanabilen biri için daha kolay olabilir. A1 düzeyinde şimdiki zaman (-yor) öğretilir ve şimdiki zamandan sonra şimdiki zamanın (-mAktA) öğretilmesi öğrencide geriye ket vurmaya ve şimdiki zaman (-yor) eki kullanması gerektiği yerde şimdiki zamanın (-mAktA) ekini kullanmasına neden olabilir.

Aynı düzey okuma kitabında birleşik çekimlerden sadece "şimdiki zamanın hikâyesi (-yordu), şimdiki zamanın koşulu (-yorsa) ve geniş zamanın koşulu” kullanılmıştır. Kitabın düzeyi hem A2 hem de B1'e yönelik olduğundan A2'deki bir öğrencinin bir düzey sonra kullanabileceği birleşik çekimleri metinden hareketle öğrenmesi amaçlanmış olabilir. 
B1-B2 düzeyi okuma kitaplarında basit zamanlardan "şimdiki zaman (-yor), belirli geçmiş zaman, gelecek zaman, öğrenilen geçmiş zaman ve geniş zaman" kullanılmıştır. Aynı düzey okuma kitabında birleşik çekimlerden "şimdiki zamanın hikâyesi (-yordu), öğrenilen geçmiş zamanın hikâyesi, geniş zamanın hikâyesi, gelecek zamanın hikâyesi, şimdiki zamanın rivayeti (-yormuş), gelecek zamanın rivayeti, şimdiki zamanın koşulu (-yorsa), geniş zamanın koşulu ve gelecek zamanın koşulu geçmektedir. B1 ve B2 bağımsız düzeydir ve bu düzeyindeki bir öğrenci herhangi bir dilbilgisi yapısını bilmiyor dahi olsa belli bir sözcük hazinesine sahip olduğu ve dilin mantığını kavradığı için metinden hareketle de anlamı tahmin edebilir. Nitekim bu dilbilgisi yapıları B2 düzeyindeki birinin bildiği yapılardır. Ancak her ne kadar B1 ve B2 düzeyi bağımsız düzey olsa da bu iki düzeydeki bireyin dil yeterlikleri arasında farklllıklar vardır. Bu yüzden A2 düzeyindeki bir kitabı A1 düzeyindeki bir öğrenci, B2 düzeyindekini B1 düzeyinde bir öğrenci daha zor kavrayabilir. A2-B1 düzeyi için hazırlanmış olan okuma kitabında da A2 düzey temel düzeyken B1 bağımsız düzeydir. Bu yüzden düzeye uygun kitap hazırlarken tek bir düzeye yönelik olması önemlidir. Diller için Avrupa Ortak Çerçeve Metni'nde dil düzeylerinde temel düzey A1-A2; bağımsız düzey B1-B2; yetkin düzey ise C1C2'dir fakat her dil düzeyinin sahip olması gereken yeterlikler birbirinden farklıdır. Bu açıdan bir dil öğretim aracı hazırlanırken her düzey öğrenci kendi içinde değerlendirilmeli ve söz varlığı, kullanılan dilbilgisi konuları, cümle ve metin uzunlukları hedef kitleye uygun hazırlanmalıdır.

\section{İkinci alt probleme yönelik sonuçlar}

İncelenen kitaplarda geçen ek eylemlere bakıldığında YEE ek eylemlere en çok A2-B1 düzeyi okuma kitabında (s 236) ve B1-B2 düzeyi okuma kitabında (s 207); en az ise A1-A2 düzeyi okuma kitabında (s 121) yer vermiştir. Ek eylemin geniş/şimdiki zamanı, zamansal ek eylem (idi) ve kanıtsal ek eylem (imiş); öğrenilmesi sürecinde birden fazla kuralı aynı anda kullanmayı gerektirmez. Belirli geçmiş zamanı ve öğrenilen geçmiş zamanı öğrenen bir kişi zaten bunları da kolayca kullanabilecektir. Ek eylemin bu çekimleri sözlü ve yazılı dilde ve okuma kitaplarında sıklıkla kullanılır. Bu yüzden incelenen kitaplarda ek eylemlere sıklıkla yer verildiği söylenebilir.

\section{Üçüncü alt probleme yönelik sonuçlar}

YEE tarafından Türkçenin yabancı dil olarak öğretimi amacıyla hazırlanmış olan A1-A2, A2-B1 ve B1B2 okuma kitaplarındaki etkinlikler incelendiğindeyse 8 farklı türde etkinlik kullanıldığı belirlenmiştir. Bu etkinliklerden en çok "eşleştirme" (s 10), "sıralama (kontrollü yazma)" (s 7), "doğru kelimeyi seçme" (s 6); en az "boşluk doldurma” (s 5), "doğru yanlış soruları" (s 5), "çoktan seçmeli” (s 4), "var-yok soruları" (s 2), "gönderim sorusu" (s 1) kullanılmıştır. A2-B1 düzeyi okuma kitabında "boşluk doldurma, eşleştirme, doğru yanlış, var-yok, doğru kelimeyi seçme, çoktan seçmeli, sıralama (kontrollü yazma), gönderim” etkinlik türlerinin hepsi kullanılmışken A1-A2 düzeyi okuma kitabında "boşluk doldurma, var-yok sorusu ve gönderim sorusu" haricinde A2-B1 düzeyi okuma kitabında kullanılan tüm etkinlik türleri kullanılmıştır. B1-B2 düzeyi okuma kitabında ise bu etkinlik türlerinden sadece "eşleştirme ve sıralama (kontrollü yazma)" etkinlikleri kullanılmıştır. Etkinlikler hazırlanırken kullanılan tekniklerin düzeye uygun olması önemlidir. Boşluk doldurma, doğru yanlış soruları, var-yok soruları, çoktan seçmeli sorular, doğru kelimeyi seçme, eşleştirme; temel düzeyde öğrencilerin kullanabileceği tekniklerdir ve daha çok okuduğunu anlamayı ölçmeye yöneliktir. İncelenen okuma kitaplarında doğrudan doğruya bilgi ve kavrama düzeyi sorular kullanıldığı, tahmin ve çıarıma dayalı soruların olmadığı görülmektedir. Yazma becerisinin de geliştirilmesi ve öğrencilerin kullandığı dil yapılarının doğruluğunu ve yanlışlı̆̆ını ölçmek için B1-B2 düzeyine yönelik kitaplarda cümle tamamlama ya da açık uçlu sorulara yer verilebilir. Nitekim bu düzeyde bir öğrenci analiz sentez 
sorularını yapabilecek yeterliktedir ve bu sorular ile öğrencilerin üst düzey bilişsel becerileri ölçülebilir. Çoktan seçmeli soruda, eşleştirmede ya da var-yok sorusunda tesadüfen doğru cevap bulunabilir. Açık uçlu ya da cümle tamamlama soruları ile bu durum önlenebilir. Türkçenin yabancı dil olarak öğretimi için hazırlanmış ders kitaplarındaki metin altı sorularının ve etkinliklerin incelendiği çalışmalarda da (Aydoğan ve Aytekin, 2019; Biçer, 2019; Kana ve Güney, 2020; Karatay ve Kaya 2019b; Şahin, 2010; Şimşek, 2011; Ulutaş ve Kara, 2019) benzer sonuçlara ulaşllmıştır. Öyleyse yazarlar tarafından daha çok bilgi ve kavrama düzeyi öğretim etkinliklerinin hazırlandığı söylenebilir. Sonuç olarak Türkçenin yabancı dil olarak öğretimi amacıyla hazırlanan kitaplarda kullanılan hem dilbilgisel yapıların hem de etkinlik türlerinin düzeylere uygun hazırlanması gerekmektedir. Dil öğretim materyallerinin öğrencilerin dil düzeylerine uygun hazırlanması daha verimli bir öğretim sürecini de beraberinde getirecektir. Türkçenin yabancı dil olarak öğretimi amacıyla kitap hazırlayacak olanlara aşağıdakiler önerilebilir:

\section{Öneriler}

1. Türkçenin yabancı dil olarak öğretimi amacıyla okuma kitapları hazırlanırken kitaplarda kullanılan dilbilgisi yapılarında dil düzeylerine uygunluğa dikkat edilebilir.

2. Okuma kitaplarındaki dil düzeyleri Diller için Avrupa Ortak Öneriler Çerçeve Metni’ndeki düzeylere göre belirlenebilir.

3. Bir okuma kitabı birden fazla düzeye göre değil, bir düzeye yönelik hazırlanabilir.

4. Kitaplarda kullanılan etkinlik türleri artırllabilir, kullanılan teknikler dil düzeyine göre belirlenebilir.

\section{Kaynakça}

Arslan, M. (2011). Yabancllara Türkçe öğretim kllavuzu temel seviye. Ankara: Nobel Akademik Yayıncillk.

Aydoğan, K. ve Aytekin, H. (2019). Yabancı dil olarak Türkçe öğretiminde set halinde kullanılan "İstanbul" metot kitaplarında okuma metinleri ve metin altı soruları üzerine bir değerlendirme, Uluslararası Sosyal Araştırmalar Dergisi, 12 (67), 5-11.

Biçer, N. (2019). Yabancılara Türkçe öğretimi ders kitaplarındaki okuma ve dinleme etkinliklerinin yenilenmiş Bloom Taksonomisine göre değerlendirilmesi, Türkçenin Yabancı Dil Olarak Öğretiminde Yeni Yönelimler, 5. Uluslararası Yabancı Dil Olarak Türkçe Öğretimi Kongresi (Ed. İ. Güleç, E. Sella, A. Okur, B. İnce), Sakarya Üniversitesi TÖMER Yayınları, Sakarya. (s. 179193).

Doyumğaç, İ. (2017). Yabancılar için Türkçe ders kitaplarında dil bilgisi öğretimi (Yayımlanmamış Yüksek Lisans Tezi). Adıyaman Üniversitesi Sosyal Bilimler Enstitüsü, Adıyaman.

Eren Ökten, C. ve Sauner-Leroy, M.H. (2016). Yabancı dil olarak Türkçe öğretimindeki kip ve zaman anlayışı değerlendirmeleri ve önerileri, Yabancılara Türkçe Öğretimi Üzerine Araştırmalar, (Ed. A. Okur, B. İnce, İ. Güleç), Sakarya Üniversitesi Yayınları.

Erol, H. F. (2008). Yabancı dil olarak Türkçe öğretiminde bildirme ve tasarlama kiplerinin öğretimi ve sıralaması (Yayımlanmamış Yüksek Lisans Tezi). İstanbul Üniversitesi Sosyal Bilimler Enstitüsü, İstanbul.

Fidan, Ö ve Aksu, C. (2011). Türkçe sözlü söylemde gereklilik/zorunluluk biçimleri ve yabancı dil olarak Türkçe öğretimi. Türkçe Öğretimi Üzerine Çalışmalar (Haz: V. D. Günay, Ö. Fidan, B. Çetin ve F. Ylldız). İzmir: Dokuz Eylül Üniversitesi Yayınları. (s. 235-244) 
Fidan, D. (2016). Türkçenin yabancı dil olarak öğretimi ders kitaplarındaki dil bilgisi konuları ve öğretmen-öğrenici görüşleri. Turkish Studies, 11(14), 257-276.

Güçer, H. (2010). -(A/I)r biçimbiriminin betimlenmesinde kuram ve yabancllara öğretilmesinde yöntem sorunları. (Yayımlanmamış Yüksek Lisans Tezi), Dokuz Eylül Üniversitesi Eğitim Bilimleri Enstitüsü, İzmir.

Gümüş, İ. (2016). Türkçede emir-istek kipi ve yabancılara Türkçe öğretimi, Selçuk Üniversitesi Türkiyat Araştırmaları Dergisi, (39), 253-262.

Gün, M. ve Şimşek, R. (2017). Yabancılara Türkçe öğretiminde kullanılan hikâye kitaplarının incelenmesi: Yunus Emre Enstitüsü Türkçe öğretimi A1-A2 hikâye seti örneği 3, International Journal of Languages' Education and Teaching, 5 (3), 502-517.

Hacıömeroğlu, M. S. (2007). Yabancı dil olarak Türkçe öğrenenler için kiplik öğretimi üzerine materyal geliştirme, (Yayımlanmamış Yüksek Lisans Tezi), Dokuz Eylül Üniversitesi Eğitim Bilimleri Enstitüsü, İzmir.

Kaili, H. ve Çeltek, A. (2010). Türkçe okuma kitabı. Yabancı Dil Olarak Türkçe Öğretiminde Yeni Çalışmalar 8. Dünyada Türkçe Öğretimi Sempozyumu Bildirileri, Ankara Üniversitesi TÖMER Yaymları, 134-145.

Kalfa, M. (2018). İşlevsel dil bilgisi. İstanbul: YDS Publishing.

Kana, F. ve Güney, Z. E. (2020). Yabancılara Türkçe öğretimi ders kitaplarında bulunan metin altı soruların yenilenmiş Bloom taksonomisine göre analizi, RumeliDE Dil ve Edebiyat Araştırmaları Dergisi, (19), 141-161. DOI: 10.29000/rumelide.752222.

Karababa, Z. C. ve Saltık, O. (2012). Yabancı dil olarak Türkçe öğretiminde buyrum ve istek kipinin görünümü ve işlevleri. Anadolu Üniversitesi Sosyal Bilimler Dergisi, 12 (3), 179-189.

Karatay, H. ve Kaya, S. (2019a). Türkçenin yabancı dil olarak öğretiminde dilbilgisi için çerçeve program. International Journal of Languages' Education and Teaching, 7 (2), 1-59.

Karatay, H. ve Kaya, S. (2019b). Türkçenin yabancı dil olarak öğretiminde bağlaçlar için çerçeve program. International Journal of Languages' Education and Teaching, 7 (4), 1-23.

Kılıçarslan, R. (2015). Yabancı dil olarak Türkçenin öğretiminde temel seviye öğrencilerinin haber ve dilek kiplerini kullanımı, International Journal of Languages' Education and Teaching, Special Issue (UDES 2015), 2303-2315.

Kurbaş, G. (2019). Yabancı dil olarak Türkçe öğretiminde senaryo temelli öğrenme modeline göre dolaylı geçmiş zaman için bir uygulama örneği. Hacettepe Üniversitesi Türkiyat Araştırmaları Enstitüsü Yabancı Dil Olarak Türkçe Öğretimi Doktora Programı 1. Öğrenci Sempozyumu (Bildiriler), (Ed. M. Durmuş), Ankara: Nobel Akademik Yayıncıllk, 201-216.

Kurt, M. (2016). Türkçenin yabancı dil olarak öğretiminde dil bilgisi. F. Yıldırım, B. Tüfekçioğlu (Ed.), Yabancı Dil Olarak Türkçe Öğretimi, Kuramlar-Yöntemler-Beceriler-Uygulamalar (261-266). Ankara: Pegem Akademi.

Özdemir, M. (2011). Yabancı dil olarak Türkçe öğretiminde edatlar (Yayımlanmamış Yüksek Lisans Tezi). T.C. İstanbul Üniversitesi Sosyal Bilimler Enstitüsü, İstanbul.

Pirinç, D. (2010). Yabancı dil olarak Türkçe öğretiminde ortaçlarn incelenmesi ve öğretimi-yeni Hitit yabancılar için Türkçe ders kitabı orta 2 örneğinde (Yayımlanmamıș Yüksek Lisans Tezi). İstanbul Üniversitesi Sosyal Bilimler Enstitüsü, İstanbul.

Sarıçiyil, F. (2008). İstek ve emir kiplerinin öğretimi. (Yayımlanmamış Yüksek Lisans Tezi), Dokuz Eylül Üniversitesi Eğitim Bilimleri Enstitüsü, İzmir.

Şahin, A. (2010). Avrupa dil gelişim dosyası bağlamında yabancı dil olarak Türkçe öğretiminde okuma becerisini geliştirmeye yönelik malzeme oluşturma (Yayımlanmamış yüksek lisans tezi). Dokuz Eylül Üniversitesi, İzmir.

Şeylan,. A. (2013). Yabancı dil olarak Türkçe öğretimi: Şimdiki zaman öğretme tekniği, Beykent Üniversitesi Sosyal Bilimler Dergisi, 6 (1), s. 29-47. 
Analyzing of Turkish teaching as a foreign language reading books in terms of activities, simple tenses, compound conjugations and substantive verbs / S. Kaya; S. K. Dolunay (pp. 1-14)

Şeylan, A. (2015). Yabancı dil olarak Türkçe öğretiminde fiil çekimi ve fiil çekimlerindeki düzensizlikler, International Journal of Languages' Education and Teaching, Special Issue (UDES 2015), 110-124.

Şimşek, P. (2011). Yabancılara Türkçe öğretiminde okuma metinleri ve yardımcı okuma kitapları üzerine bir araştırma (Yayımlanmamış Yüksek Lisans Tezi). Afyon Kocatepe Üniversitesi, Afyon.

Ulutaş, M. ve Kara, M. (2019). Yabancı dil olarak Türkçe öğretimi ders kitaplarındaki metin altı sorularının yenilenmiş Bloom Taksonomisi’ne göre incelenmesi. Uluslararası Türkçe Edebiyat Kültür Ĕ̆itim Dergisi, 8 (4), 2198-2214.

Ünlücömert, N. (2010). -mIş biçimbiriminin farkh işlevlerinin bilinç uyandirma teknikleriyle öğretimine yönelik malzeme oluşturma, (Yayımlanmamış Yüksek Lisans Tezi), Dokuz Eylül Üniversitesi Eğitim Bilimleri Enstitüsü, İzmir.

Yolcusoy, Ö. (2008). Türkçe koşullu yapıların öğretimine yönelik malzeme tasarım, (Yayımlanmamış Yüksek Lisans Tezi), Dokuz Eylül Üniversitesi Eğitim Bilimleri Enstitüsü, İzmir. 